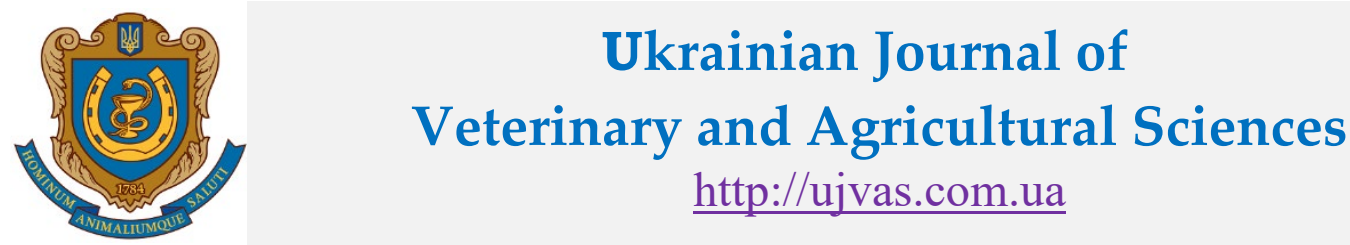

Stepan Gzhytskyi National University of Veterinary Medicine and Biotechnologies Lviv

\begin{tabular}{l|l|l} 
original article & UDC 639.2.053.2 & doi: 10.32718/ujvas2-3.07
\end{tabular}

Volume 2

Number 3

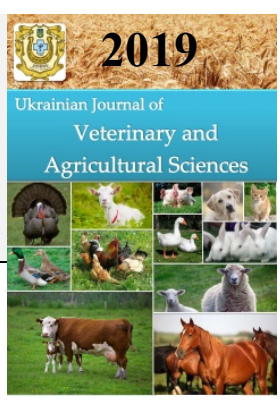

\title{
Analysis of water quality of a reservoir on a small river and the status of ichthyofauna in anthropogenic conditions
}

\author{
I. O. Parfenyuk ${ }^{1}$, Yu. R. Grokhovskaya ${ }^{1}$, Yu. M. Mandygra ${ }^{2}$ \\ ${ }^{I}$ National University of Water Management and Environmental Management, Soborna, Str., 11, Rivne, 33028, Ukraine \\ ${ }^{2}$ Institute of epizootology IVM NAAS, Prince Vladimir, Str., 16/18, Rivne, 33028, Ukraine
}

\begin{tabular}{|c|}
\hline $\begin{array}{l}\text { Article info } \\
\text { Received } 06.11 .2019 \\
\text { Received in revised form } \\
\quad 06.12 .2019 \\
\text { Accepted } 07.12 .2019\end{array}$ \\
\hline $\begin{array}{l}\text { Correspondence author } \\
\text { Ilona Parfenuk } \\
\text { Tel.: +38-097-947-12-36 } \\
\text { E-mail: Yakovina_ilona@ukr.net }\end{array}$ \\
\hline $\begin{array}{l}2019 \text { Parfenyuk I. et al. This is an } \\
\text { open-access article distributed under } \\
\text { the terms of the Creative Commons } \\
\text { Attribution License, which permits } \\
\text { unrestricted use, distribution, and } \\
\text { reproduction in any medium, } \\
\text { provided the original author and } \\
\text { source are credited. }\end{array}$ \\
\hline$(\mathrm{cc}) \mathrm{Br}_{\mathrm{Br}}$ \\
\hline $\begin{array}{ll}\text { Contents } & \\
\text { 1. Introduction ................. } & 28 \\
\text { 2. Materials and methods ...... } & 29 \\
\text { 3. Results and discussion ...... } & 29 \\
\text { 4. Conclusions ................. } & 30 \\
\text { References ................... } & 30\end{array}$ \\
\hline
\end{tabular}

\begin{abstract}
The surface waters of the estuaries of the estuary are mostly characterized by low quality, which was formed as a result of considerable anthropogenic loading and transformation of the catchment area. The monitoring data of the ecological and sanitary status of the surface waters of the Basov Kut reservoir are presented, as well as the results of accounting for dead fish due to the frosts that occurred in the mouth of the Ustye River during 2011-2017. It is established that the Bas Basin is not suitable for recreational use. Amateur fisheries are also a danger to the population, as lactose-positive E. coli, the Staphylococcus aureus index, the Enterococcus microorganism index, Lamblia intestinalis cysts and eggs are detected in this reservoir annually. In 2017, cholera vibrios (Vibrio cholera non O1) were detected. Hydrochemical indicators, in particular in 2018, revealed inconsistency with the following indicators: odor - 2 points; color 3; BOD5 - 6.5-7.5 mgO $/ \mathrm{dm}^{3}$; COD 40-50 $\mathrm{mgO}_{2} / \mathrm{dm}^{3}$. In samples tested for sanitary - microbiological and parasitological parameters, cholera - like vibrio (non O1) was detected. The deterioration of water quality by the content of biogenic elements, in particular, compounds of Nitrogen and Phosphorus, which leads to increased eutrophication of the reservoir. The "flowering" of water in 2018 began in the third decade of June and lasted until October. This process harms not only hydrobionts, but also humans, as blue-green algae toxins can accumulate in fish tissues and cause poisoning when consumed by such products. In addition, there was a significant percentage of fish that did not meet the requirements of DSTU 2284: 2010 in terms of organoleptic characteristics. The greatest damage to the populations of fish that inhabit the Estuary during the fatalities was caused in 2012. When the estimated loss of fishery resources amounted to 377.4 thousand individuals, according to scientists and control bodies. Annual fatalities have led to quite significant losses of populations of industrially valuable fauna. A significant loss of fishery resources was noted in 2017 - about 10.32 thousand. It was noted that the following populations of fish were most affected by the frost in the estuary: Rutilus rutilus, Scardinius erythrophthalmus, Leucaspius delineatus, Perca fluviatilis, Carassius gibelio, Tinca tinca, Esox lucius, Sander luciocaper, Abracerperis This poses a significant threat to the further reproduction of ichthyofauna in the mouth of the Ustya River, and also calls into question the possibility of amateur fishing in these sites.
\end{abstract}

Key words: the surface waters, anthropogenic loading, transformation, monitoring.

\section{Citation:}

Parfenyuk, I. O., Grokhovskaya, Yu. R., \& Mandygra, Yu. M. (2019). Analysis of water quality of a reservoir on a small river and the status of ichthyofauna in anthropogenic conditions. Ukrainian Journal of Veterinary and Agricultural Sciences, 2(3), $28-31$.

\section{Introduction}

The surface waters of the estuaries of the estuary are mostly characterized by low quality, which was formed as a result of considerable anthropogenic loading and transformation of the catchment area. One of the objects of the Ustya River Basin is the Basov Kut reservoir, which was created in the early twentieth century and is used for recreational, recreational and sport fishing. Back in the 1980s, according to the data of the Ustya River passport, the water in the reservoir was relatively clean, and by the beginning of the 21 st it was dangerous to use fish caught from it and to swim. Annually, after 2015 by the regulatory bodies, a ban on bathing in this reservoir is established. And the phenomenon of "flowering water", according to field observations, begins in June and ends in October. This change is the result of discharges of untreated domestic and municipal wastewater into the river from settlements located above the reservoir (Zdolbunov town, Kvasiliv township, Novy Dvor village), as well as discharges from large industrial enterprises (Volyn-cement). Negative changes in the ecosystems of the reservoirs of the mouth of the Usti River continue. Due to climatic changes, changes in water bodies in reservoirs, changes in hydrochemical and hydrobiological regimes, the composition of ichthyofauna in the studied reservoirs is significantly. The processes of population decline and the complete disappearance of sensitive and industrially valuable species have accelerated significantly. The quality of fishery products in terms of organoleptic, microbiological and morbidity rates has significantly deteriorated (Iakubchak et al., 2005; Davydov et al., 2007; Grynevych et al., 2018; Prysiazhniuk et al., 2019; Fedorovych et al., 2019). Analysis of 
literature and scientific sources has shown that the ecological status of the reservoir is threatening and poses a danger not only to the biota of the reservoir but also to human health (Klymenko \& Hrokhovska, 2006; Klymenko et al., 2016; Hrokhovska, 2017; Hrokhovska \& Konontsev, 2018).

The purpose of the work was to analyze the water quality of the reservoir on a small (middle river according to the Water Framework Directive) river and to study the status of ichthyofauna in anthropogenic conditions.

\section{Materials and methods}

Investigations were carried out in certain estuaries of the Usti River and Basov Kut reservoir according to certain methods.

Hydrochemical, sanitary - microbiological and parasitological parameters were investigated by specialists of Rivne laboratory center. In addition, data from the reports of the Main State Directorate of Conservation, Use and Reproduction of Aquatic Living Resources and Regulation of Fisheries in Rivne Region were used.

The results were processed using Microsoft Excel software.

\section{Results and discussion}

In 2014, an Association Agreement between Ukraine and the European Union was signed, which obliged Ukraine to introduce European standards in the field of water resources management, water protection and pollution control, in particular to introduce the provisions of the EU Water Framework Directive into the Water Code of Ukraine, in general, the practice of water resources management in Ukraine (Khilchevskyi \& Hrebin, 2017).

However, the provisions of the WFD are not designed for the critical ecological status of most of our country's water bodies. Therefore, in order to assess the ecological status of the surface waters of river basins, it is necessary to take into account the sanitary and hygienic indicators, which will make it possible to comprehensively assess the state of the object and determine the degree of danger to the population.

In 2017, the Ministry of Health of Ukraine initiated the creation of a draft order approving the hygiene standards for water quality of water bodies to meet drinking, household and other needs of the population (in accordance with Article 18 of the Law of Ukraine "On Ensuring Sanitary and Epidemic Well-Being of the Population"). And submitted for state registration to the Ministry of Justice of Ukraine.

According to this project, the Bas Basin belongs to the second category of water use. We conducted an analysis of the conformity of surface water quality of the Basov Kut reservoir with the requirements of "Hygienic water quality standards of water bodies for meeting drinking, household and other needs of the population" according to the indicators determined by the Rivne Regional Laboratory Center. The results of the analysis according to the data of Rivne Oblast Laboratory Center are presented in Table 1.

Table 1

Characteristics of surface waters of the Basov Kut reservoir

\begin{tabular}{lcccl}
\hline \multicolumn{1}{c}{ Indicators } & 2013 & 2016 & 2017 & \multicolumn{1}{c}{ Normative } \\
\hline Scent & Responds & Responds & $\begin{array}{c}\text { Not Responsive } \\
\text { (5 Years Over) }\end{array}$ & $\begin{array}{l}\text { less than 1 point is detected } \\
\text { directly }\end{array}$ \\
Hydrogen $\mathrm{pH}$ & Responds & Responds & Not Responsive & $6.5-8.5$ \\
Mineral composition & Responds & Responds & Biдnовiдa€ & $<1000 \mathrm{mg} / \mathrm{dm}^{3}$ \\
Dissolved oxygen & Responds & Responds & Not Responsive & $>4 \mathrm{mg} / \mathrm{dm}^{3}$ \\
Pathogens & Not Responsive & Not Responsive & Not Responsive & There are no pathogens \\
LKP & Not Responsive & Not Responsive & Not Responsive & Not more than $5000 / \mathrm{dm}^{3}$ \\
Coliphages (in plaque-forming units) & Not Responsive & Not Responsive & Not Responsive & Not more than $100 / \mathrm{dm}^{3}$ \\
Viable helminth eggs & Not Responsive & Not Responsive & Not Responsive & Should not be contained in $1 \mathrm{dm}^{3}$ \\
\hline
\end{tabular}

Over the years, the reservoir has been found to have an excess of the index of lactose-positive Escherichia coli, the index Staphylococcus aureus, the index of microorganisms of the genus Enterococcus. Cysts of Lamblia intestinalis and helminth eggs are detected annually. In 2017, cholera vibrios (Vibrio cholera non O1) were detected.

In 2018, the water of this reservoir did not meet the standards for the following indicators: odor -2 points; color 3; BOD5 - 6.5-7.5 mgO $/ \mathrm{dm}^{3}$; COD $40-50 \mathrm{mgO}_{2} / \mathrm{dm}^{3}$. In samples tested for sanitary - microbiological and parasitological parameters, cholera - like vibrio (non O1) was detected; the LKP titer exceeded the norm by 48 times; $E$. coli - 48 times, samples of helminth eggs and giardia cysts were detected in the samples.

Monitoring results indicate that water quality in the reservoir is rapidly deteriorating and is currently catastrophic. The main causes of this process are the non-compliance with the legislative requirements for the protection of water resources, in particular, the continuing discharge of untreated municipal utilities from households. In addition to the indi- cators analyzed above, there is a deterioration of the water quality by the content of biogenic elements, in particular, Nitrogen and Phosphorus, which leads to increased eutrophication of the reservoir. In particular, the phenomenon of "flowering" of water on this reservoir in 2018 began in the third decade of June (up to maximum temperatures) and lasted until October. Such a process is harmful not only to aquatic organisms, but also to humans, since blue-green algae toxins are able to accumulate in fish tissues and cause poisoning when consumed by such products (Misejko et al., 2001).

In addition, such a rapid deterioration of surface water quality leads to the impoverishment of ichthyofauna. According to the reports of the Rivne Fisheries Patrol, over a 10 -year period, the fish, which caused a sharp decrease in the dissolved water content, was observed almost annually on the Ustya River (within the reservoir water area and in the watercourse section within the Rivne city). oxygen (Table 2). This process was due to the complex action of abiotic, biotic and anthropogenic factors - a decrease in 
saturation due to increase in water temperature and increase of biomass of blue-green algae to the level of "flowering" of water due to anthropogenic eutrophication.

The greatest damage to the populations of fish that inhabit the Estuary during the fatalities was caused in 2012. When the estimated loss of fishery resources amounted to
377.4 thousand individuals, according to scientists and control bodies. In the subsequent period (2013-2016), the annual fatalities led to quite significant losses of populations of industrially valuable fauna. A significant loss of fishery resources was noted in 2017 - about 10.32 thousand.

\section{Table 2}

Results of accounting for dead fish on the Ustye River due to suffocation (according to the data of Rivne Fish Protection Patrol 2011-2017)

\begin{tabular}{|c|c|c|c|c|}
\hline $\begin{array}{l}\text { № } \\
\text { 3/ח }\end{array}$ & Year & Plot of watercourse & Species composition of dead specimens of fish & $\begin{array}{l}\text { Number of fish killed, } \\
\text { copies }\end{array}$ \\
\hline 1 & 2011 & $\begin{array}{l}\text { R. Ustya within the city of } \\
\text { Rivne }\end{array}$ & $\begin{array}{c}\text { Sander lucioperca, Rutilus rutilus, } \\
\text { Carassius gibelio, Leucaspius delineatus }+ \text { Albur- } \\
\text { nus alburnus }\end{array}$ & 14220 \\
\hline 2 & 2012 & $\begin{array}{l}\text { R. Ustya (upper basin of } \\
\text { Basov Kut reservoir and } \\
\text { within the city of Rivne) }\end{array}$ & $\begin{array}{c}\text { Rutilus rutilus, Scardinius erythrophthalmus, Leu- } \\
\text { caspius delineatus, Perca fluviatilis, Carassius } \\
\text { gibelio, Tinca tinca, Esox lucius }\end{array}$ & 377400 \\
\hline 3 & 2013 & $\begin{array}{l}\text { R. Ustya (upper basin of } \\
\text { Basov Kut reservoir) }\end{array}$ & Rutilus rutilus, Perca fluviatilis & 3034 \\
\hline 4 & 2014 & $\begin{array}{l}\text { R. Ustya within the city of } \\
\text { Rivne }\end{array}$ & $\begin{array}{l}\text { Rutilus rutilus, Esox lucius, Alburnus alburnus, } \\
\text { Perca fluviatilis, Leucaspius delineatus }\end{array}$ & 1558 \\
\hline 5 & 2015 & $\begin{array}{l}\text { R. Ustya (upper basin of } \\
\text { Basov Kut reservoir) }\end{array}$ & Rutilus rutilus, Perca fluviatilis, Sander lucioperca & 4656 \\
\hline 6 & 2016 & $\begin{array}{l}\text { R. Ustya within the city of } \\
\text { Rivne }\end{array}$ & $\begin{array}{c}\text { Rutilus rutilus, Perca fluviatilis, Leucaspius delin- } \\
\text { eatus, Blicca bjoerkna }\end{array}$ & 3224 \\
\hline 7 & 2017 & $\begin{array}{l}\text { R. Ustya within the city of } \\
\text { Rivne }\end{array}$ & $\begin{array}{l}\text { Rutilus rutilus, Leucaspius delineatus, Perca fluvi- } \\
\text { atilis, Carassius gibelio, Sander lucioperca, Abra- } \\
\text { mis brama, Blicca bjoerkna }\end{array}$ & 10320 \\
\hline
\end{tabular}

Neglect of the protection of surface waters from pollution leads to danger during rest and depletion of the country's natural resources, in particular, species diversity of ichthyofauna and quality of fishery products. Conservation of aquatic ecosystems is an important task for society and, in this context, the positive experience of European Union countries on the restoration of quality and protection of surface waters should be exploited.

\section{Conclusions}

1. During 2013-2017 the basin Kut reservoir was found to have an excess of the index of lactose-positive Escherichia coli, the index of Staphylococcus aureus, the index of microorganisms of the genus Enterococcus. Cysts of Lamblia intestinalis and helminth eggs are detected annually. In 2017, cholera vibrios (Vibrio cholera non O1) were detected.

2. In 2018, the water of this reservoir did not meet the standards for the following indicators: odor -2 points; color 3; BOD5 - 6.5-7.5 $\mathrm{mgO}_{2} / \mathrm{dm}^{3}$; COD 40-50 $\mathrm{mgO}_{2} / \mathrm{dm}^{3}$. In samples tested for sanitary - microbiological and parasitological parameters, cholera - like vibrio (non O1) was detected; the LQP titer was $>240.000 \mathrm{cu} / \mathrm{dm}^{3} ;$ E. coli $>$ 240000 , helminth eggs, giardia cysts were detected in the samples.

3. Water quality in the reservoir is deteriorating very quickly and is currently catastrophic. The deterioration of water quality by the content of biogenic elements, in particular, Nitrogen and Phosphorus, which leads to increased eutrophication of the reservoir. In particular, the phenomenon of "flowering" of water on this reservoir in 2018 began in the third decade of June (up to maximum temperatures) and lasted until October.
4. The greatest damage to the populations of fish found in the Estuary during the fatalities was caused in 2012. When the estimated loss of fishery resources amounted to 377.4 thousand individuals, according to scientists and control bodies. In the subsequent period (2013-2016), the annual fatalities led to quite significant losses of populations of industrially valuable fauna. A significant loss of fishery resources was noted in 2017 - about 10.32 thousand.

\section{References}

Davydov, O. N., Abramov, A. V., \& Temnihanov, Ju. D. (2007). Veterinarno-sanitarnyj kontrol' pishhevyh gidrobiontov. Cherkassy, uzd-vo "ANT" (in Russian).

Dudnyk, S. V., \& Yevtushenko, M. Iu. (2013). Vodna toksykolohiia: osnovni teoretychni polozhennia ta yikhnie praktychne zastosuvannia [Monohrafiia]. K.: Vyd-vo Ukrainskoho fitosotsiolohichnoho tsentru. https://nubip.edu.ua/sites/default/ files/u104/Водна\%20токсикологія-монографія.pdf (in Ukrainian)

Fedorovych, O. V., Gutyj, B. V., Fedorovych, V. S., \& Chornyi, I. O. (2019). Epizootic situation on fish invasion diseases in the waters of Ukraine. Scientific Messenger of Lviv National University of Veterinary Medicine and Biotechnologies. Series: Veterinary sciences, 21(96), 95-100. doi: 10.32718/nvlvet9617.

Grynevych, N., Sliusarenko, A., Dyman, T., Sliusarenko, S., Gutyj, B., Kukhtyn, M., Hunchak, V. \& Kushnir, V. (2018). Etiology and histopathological alterations in some body organs of juvenile rainbow trout Oncorhynchus mykiss (Walbaum, 1792) at nitrite poisoning. Ukrainian Journal of Ecology, 8(1), 402408. doi: $10.15421 / 2018228$.

Hrokhovska, Yu. R. (2017). Antropohenez i prisnovodni ekosystemy: retrospektsiia ta suchasni problemy. Tavriiskyi naukovyi visnyk: Naukovyi zhurnal, 97, 207-215. http://nbuv.gov.ua/UJRN/tnveconn_2017_97_36 (in Ukrainian). 
Hrokhovska, Yu. R., \& Konontsev, S. V. (2018). Antropohennyi vplyv na ekolohichnyi stan i strukturu bioty vodnykh ekosystem baseinu Prypiati. Mizhnarodna naukovo-praktychna konferentsiia «Ekolohichni problemy navkolyshnoho seredovyshcha ta ratsionalnoho pryrodokorystuvannia $\mathrm{v}$ konteksti staloho rozvytku» do 60-richchia vid dnia narodzhennia d.s.-h.n., profesora Pylypenka Yu.V. 25-26 zhovtnia 2018. Kherson: Oldi-plius, 390-393 (in Ukrainian).

Iakubchak, O. M., Khomenko, V. I., \& Melnychuk, S. D. (2005). Veterynarno-sanitarna ekspertyza $\mathrm{z}$ osnovamy tekhnolohii i standartyzatsii produktiv tvarynnytstva. K. (in Ukrainian).

Khilchevskyi, V. K., \& Hrebin, V. V. (2017). Hidrohrafichne ta vodohospodarske raionuvannia Ukrainy 2016 r. Realizatsiia polozhen VRD YeS. Hidrolohiia, hidrokhimiia i hidroekolohiia, 1(44), 8-20 (in Ukrainian).

Klymenko, M. O., \& Hrokhovska, Yu. R. (2006). Hidrokhimichna kharakterystyka richky Ustia. Visnyk NUVHP. Silskohospodarski nauky, 3(35), 10-17 (in Ukrainian).
Klymenko, M. O., Zaleskyi, I. I., \& Biedunkova, O. O. (2016). Prostorovyi rozpodil yakisnykh kharakterystyk vmistu vazhkykh metaliv u donnykh vidkladakh richky Ustia. Visnyk NUVHP. Silskohospodarski nauky, 3(75), 71-81. http://visnyk.nuwm.edu.ua/index.php/agri/article/view/175 (in Ukrainian)

Misejko, G. N., Bezmaternyh, D. M., \& Tushkova G. I. (2001). Biologicheskij analiz kachestva presnyh vod Barnaul: AltGU (in Russian).

Prysiazhniuk, N., Grynevych, N., Slobodeniuk, O., Kuzmenko, O., Tarasenko, L., Bevz, O., Khomiak, O., Horchanok, A., Gutyj, B., Kulyaba, O., Sachuk, R., Boiko, O., \& Magrelo, N. (2019). Monitoring of morphological parameters of Cyprinidae liver. Ukrainian Journal of Ecology, 2019, 9(3), 162-167. doi: 10.15421/2019_725. 